Article

\title{
Both Parents Working: Challenges and Strains in Managing the Reconciliation of Career and Family Life in Dual-Career Families. Empirical Evidence from Austria
}

\author{
Gerlinde Mauerer \\ Institute of Sociology, University of Vienna, 1090 Vienna, Austria; gerlinde.mauerer@univie.ac.at
}

Received: 15 September 2018; Accepted: 11 December 2018; Published: 17 December 2018

check for updates

\begin{abstract}
The presented empirical data analysis aims to shed light on the persistence of gender inequalities in sharing parenting responsibilities and addresses possible improvements for realising gender equality. In recent decades, family policies in the European Union have targeted the increase of men's shares in parental leave (=paternal leave) as well as women's participation in the labour market. Following the results of the Lisbon Treaty in 2000, many EU member states including Austria introduced non-transferable fathers' quotas in their regulations on parental leave. Subsequently, the share of men on parental leave increased. Nevertheless, both in number and duration, men's childcare allowance claims have remained lower than women's claims. This paper investigates shared parental leave practices based on 36 interviews with fathers on paternal leave, and 14 follow-up interviews with parents after paternal leave. The qualitative data reveal the challenges that arise when both parents are faced with reconciling work and family during and after parental leave. Although the data showed that progress has been made in reducing gender inequality, the interviews make clear that employers' attitudes perpetuate traditional gendered expectations of parental leave claims and still focus on images of a male breadwinner. Also, the distribution of gainful and family work reveals gender inequalities. The paper therefore discusses challenges that arise in the realisation of current gender and family policies in order to provide a basis for making changes that further enhance the opportunities for dual-career couples within the organisation of parental leave laws.
\end{abstract}

Keywords: parental leave; empirical sociological research; family research; gender equality; work-life-balance; gender at work; gender care gap; gender pay gap; Austria

\section{Introduction}

In Austria and in several EU member states, the promotion of the share of men on parental leave, synonymously called paternal leave (and commonly called Väterkarenz in German), and their share in claiming childcare allowance has been a prominent topic in family policies. Following an EU directive from 1996, which was enacted in 2000 in the Lisbon Treaty, a large number of EU member states introduced new regulations on parental leave, including non-transferable fathers' quotas and individual options for sharing childcare in the family. The new policies led to significant success in promoting fathers' involvement in the family and making men's caring roles more visible (Eydal and Rostgaard 2018; O'Brien and Wall 2017a; Crespi and Ruspini 2016; Brandth and Kvande 2016; O'Brien et al. 2007). Nevertheless, at the forefront of employers' awareness when considering parents among their staff, especially in male-dominated branches, men are seen as breadwinners and women are seen as pursuing part-time gainful employment (Bergmann and Schiffbänker 2016, p. 119f; see also Bergmann et al. 2017). According to many employers' conceptions of a work-family balance, women function as primary caregivers in a 
family. Although in individual cases this perception may differ, it nevertheless has an impact on women's participation in the labour market.

Moreover, the perception of women's gainful employment as providing extra family income is related to a dominant male family breadwinner model (Berghammer 2014; Walden 2016, p. 120). This perception is deeply rooted in the organisation of labour legislation, which has been established since the mid nineteenth century and has, since 1900, had its fundaments in the Civil Law Code (Hausen 1997, p. 714f; Neyer 1997). Since their founding, social policies and labour regulations have been closely intertwined with gender politics (ibid.). Since the end of the Second World War, putting Austrian labour legislation into practise in the work place, in organisations and companies, has been regulated by the social partnership, a committee of employers, employees and their unions, and an instrument of dialogue, which initially included mainly men. In a wider social and economic context, their negotiations included topics such as the regulation of trade-specific wages and prices. Deriving from patriarchal roots in the past, a close connection between the social partnership in Austria (and Germany) and gender politics still has an influence on women's and men's participation in the labour market. In Austria, until 1975, a man as head of a patriarchal family had to agree to his wife's decision to continue or take up gainful employment (with several exceptions during the First and Second World Wars, and also branch-specific exceptions). Since the legal reform in the Austrian family laws in 1975, married women have been allowed to work without the consent of their husbands, but voluntary marital agreements still often result in women who are part of a heterosexual couple opting for part-time work. In the past, this was seen as a basis for securing harmony within a family. Moreover, unpaid family work was "silently" included in these private agreements, which also mirrored the close connection between the social partnership in the organisation of labour laws, gender and family politics. In the functioning of the public, in organizations and, more generally, in society as a whole, gender disparities in labour market participation have been deeply rooted in the legal construction of work in Austria, Germany and a large number of European member states. The effects of this former construction have not yet been totally abolished (Eurostat 2016). As a result, and due to a persistent gender pay and gender care gap, women's participation in the workforce has remained, on average, lower than men's (ibid.).

The gathered empirical data on paternal leave in Austria revealed that during periods of paternal childcare allowance claims, fathers followed the idea of a male breadwinner model and family income provider, parallel to fulfilling caring tasks for the family and their offspring. If they and the employer agreed, men remained in part-time work, fulfilling smaller or even larger projects in their current workplace or a different one during the period of claiming childcare benefits (see Rille-Pfeiffer et al. 2018, pp. 58-60). The Austrian parental leave system provides parental leave until a child has reached the age of two as an entitlement per family (ibid. 2018, p. 58). In 2002, parental leave benefits were replaced by childcare benefits, which has led to an increase in men's shares in allowance claims. In 2015, according to Statistics Austria, the share of men as childcare allowance receivers was 4.17 percent in total (measured in days on leave), and 6.2 percent in the income-related model.

"Due to the fact that fathers mainly take shorter periods than mothers-they choose the shorter option more often than women, as the payment is higher than for the longer options-and therefore appear less often in the statistics. Looking at fathers who have taken any period of childcare benefit, the percentage is much higher, varying between the different options from 10.72 percent to 30.63 percent [April 2016, children before March 2017]." (Rille-Pfeiffer et al. 2018, p. 63)

In investigating the reasons for persistent gender imbalances in claiming childcare allowance, the presented qualitative research provides empirical data and an analysis of it. Included are guideline interviews with men who took parental leave for a relatively long period (most for more than two or three months). Moreover, to a smaller extent, interviews with partners were included in a follow-up research (project 3). The qualitative interview material with Austrian parents and data drawn using a qualitative-interpretative method provide insights into fathers' progress in personally realising 
family-centred attitudes in active childcare involvement, and in taking a pioneering role in representing caring masculinities (Elliott 2016, p. 256). Therefore, the data are relevant for investigating positive examples of men who have succeeded in reconciling work and family, in some cases in cooperation with their partner, during their paternal leave. The results contribute to research on shared parental leave practices, and, in the Austrian specific context, develop qualitative insights into men's progress in participating in childcare allowance claims, and, afterwards, to greater participation in daily family life, as the presented research has confirmed in a follow-up study.

Although empirical data show best practice examples, hidden challenges in sharing parenthood persist, caused mainly by the effects of a long tradition of a male breadwinner model (Berghammer 2014). The analysis of the data aims to shed light on influences that seemingly counteract relatively generous childcare benefits and parental leave practices. Furthermore, in an international comparison, Austrian data on public budgets earmarked for the transfer of gender-equality measures reveal high spending that leads to lower than expected results in relation to the efforts put into the financial support of gender-equality measures and programmes in recent decades. The qualitative investigation presented here thus pursues the goal of identifying and exploring the impact of persistent gender inequalities, as represented in the Austrian data in the European Gender Equality Index 2017 (EIGE 2017; see also EIGE 2015). The presented research aims to find out if, how, and why relatively good opportunities for a reconciliation of work and family by both partners have not yet resulted in higher rates of men sharing parental leave and childcare benefits on equal terms with their partners.

More recently, new family policies have offered higher compensation for both parents over a shorter time period. This is made possible by the Austrian $12+2$ income-related model, the allowance option with the highest income replacement up to a maximum of 2000 euros per month (see subchapter 3 ), which tends to result in the norm of 'both parents working', thus highlighting dual career perspectives. Although this represents a success in terms of women's labour force participation, new challenges in scheduling family life and shared parental tasks have simultaneously emerged. The presented research aims to shed light on these challenges.

At present, cultural traditions related to fatherhood, motherhood, and thereafter the impact of emotional labour are being investigated in the social sciences, including research on the cultural and emotional implications of attitudes towards parental (leave) practices and rousing men's interest in caring (Musumeci and Santero 2108; Blair-Loy et al. 2015). Examining men's participation as childcare allowance receivers is thus an eligible indicator for tracing men's individual pathways in caring and career. Research on gender at work revealed that men's short-term childcare benefit claims of roughly two months are too short for developing and showing the impact of caring masculinities as a new constant in managing family life (Walden 2016, p. 120f).

At present, the persistence of strong traditional gender codes deriving from a still-intact sex-gender-system at work and in private life tend to counteract and undermine the impact of new family policies for promoting gender equality. Currently, good income compensation and father-child-bonding, rather than the distribution of unpaid care, are foregrounded for attracting men to become childcare allowance receivers. Subsequently, analysis of the empirical data aims to identify potential changes that could support and enhance parent's pathways in equally sharing childcare responsibilities.

\section{Research Background}

In an international comparison, substantial progress has been made in Austria in the legal regulations on parental leave for both parents. However, this change in legislation has not yet effected a change in the minds of the majority of parents and families. Traditional influences deriving from a conservative gender order, which have been strengthened by the social partnership in labour legislation, still impact also so-called modern partnerships, even if couples or fathers include and realise a period of paternal leave in their childcare and career plans. 
In their development of leave policies, Austria, as well as Germany, "were moving towards a more balanced mother-centred model by offering a shorter one-year well-paid leave as well as expansion of fathers' entitlements and a gradual increase in services [ ... ]; however, they could not be considered as 'parental choice' countries since their pathway was still strongly associated with some key characteristics of the mother-centred model" (Escobedo and Wall 2015, p. 219f). Quantitative figures showing a high share of part-time work in women's gainful employment confirm this result.

International studies on parental leave and the use of childcare benefits without going on paternal leave, e.g., claiming the benefits and reducing working hours in gainful employment, which represents an option in the Austrian childcare allowance system, made apparent the fact that different national models of financing shorter- and longer-term childcare must be presented within the complexity of the respective national context. This paper consequently provides information on the Austrian childcare allowance system. In Austria, paternal leave is a common expression for men's parental leave taking, usually for two months or more. Differing from this regulation, "paternity leave" is an optional one-month leave directly after the birth of a child, with no statutory entitlement in Austria. Until February 2017, the public sector, for the most part, provided men with the opportunity to go on unpaid "paternity leave". In the private sector, this entitlement was subject to the employers' discretion and was less frequent.

However, this benefit does not include job-protection. The different terms, such as parental leave and paternal leave (=men's parental leave, which is mainly used in German speaking countries) make international comparisons difficult. In the KELA working papers on "Fathers' use of paternity and parental leave in the Nordic countries" (Haataja 2009), the author made a plea for clear definitions and a distinction between "parental leave", "paternity leave" (such as, the "Papa-month"), and "paternal leave", which is less often used, as it is included also in the definition of parental leave. The new Austrian regulations, in force since March 2017, have revised the definitions. Since then, the former option of a one-month paternity leave can be taken as a "family-time bonus" ("Familienzeitbonus"), and can be integrated into the parental leave period if the father makes use of it.

Internationally, data analyses in family research and gender equality research have focused on analysing shared parental care in terms of women's labour force participation, the share of men on parental leave, and part-time work. Their participation in the private sphere via time-use statistics and qualitative analyses focus on gender at work, for instance over-time work as a male paradigm that is influenced by national and cultural working codes (among others, Matsuda et al. 2018; Bergmann and Schiffbänker 2016) and gender in organizations (Funder 2016; Acker 2012; Collinson and Hearn 1994). An investigation of qualitative aspects in the distribution of paid and unpaid labour enables a more detailed identification of persistent gender imbalances, and supports the development of a better understanding of those factors that, although they counteract this, have not yet been implemented in current family and gender equality policies. Moreover, interrelationships between both gender equality and family policy measures are subjects of investigation (see Salin et al. 2018, p. 14f; Ciccia and Verloo 2012).

\section{Status Quo of Leave Policies and Employment-Related Policies to Support Parents in Austria}

In Austria, fathers' involvement in family care was facilitated by the legal implementation of childcare allowance in 2002, including four flat rate models with $12+2$ months, $15+3,20+4$, and $30+6$ months, with allowances beginning at 1000 euros per month in the shortest model to 436 euros in the longest model. Until February 2017, the +month annex referred to the minimum time to be taken by the father, which drew criticism, as fathers often claimed the minimum. Moreover, an income-based allowance model exists ( $12+2$ months, with a maximum of 2000 euros per month). In the income-based model, parents on leave receive 80 per cent of their previous income. This represents the shortest allowance model with the highest compensation. As men have a higher income than women, in general, a high percentage of men who take parental leave opt for this model (see Mauerer 2018, p. 185; Schmidt 2018, p. 449; Schmidt et al. 2015). Moreover, fathers tend to take the two-month portion of this leave time (Statistics Austria 2018). 
Critical evaluations of the Austrian childcare allowance system, especially in social policy, have pointed to the fact that the longest model of childcare benefits in Austria, which lasts for 3 years if both parents share the leave and includes the lowest monthly rates (see Table 1, line 4), outlasts the job security that is guaranteed during parental leave, and ends after 24 months. The Austrian researcher in European social policy Helene Dearing highlighted that this long option for claiming childcare benefits negatively effects parents', mainly mothers', gainful careers (Dearing 2016, p. 235).

Table 1. Austria's Parental Leave System since 2000, including 5 forms of childcare allowance from 2000 to February 2017 (for parents of newborn, adopted or foster children).

\begin{tabular}{|c|c|c|}
\hline One parent: 12 months & both parents: $12+2$ months $=14$ & monthly rate $1000 €$ \\
\hline One parent: 15 months & both parents: $15+3$ months $=18$ & monthly rate $800 €$ \\
\hline One parent: 20 months & both parents: $20+4$ months $=24$ & monthly rate $624 €$ \\
\hline One parent: 30 months & both parents: $30+6$ months $=36$ & monthly rate $436 €$ \\
\hline 12 (income-related) & both parents: $12+2$ months $=14$ & monthly rate $1000-2000 €$ \\
\hline
\end{tabular}

In 2010, an income-based childcare allowance model was additionally enacted with the aim of making it more attractive for men to claim childcare benefits, as their generally higher incomes resulted in higher family income compensation during the parental leave period. Nevertheless, the number of men did not increase significantly: Between 2010 and 2015, the mentioned data counting the share of men in childcare allowance claims per month showed a slight decrease, from 4.5 to 4 per cent (Statistics Austria 2016). In March 2017, a new childcare allowance system was installed in Austria, including a partner bonus of 500 euros for each parent when both share the childcare allowance period 50:50 or 60:40 in terms of time. The new allowance models aimed at increasing fathers' participation in childcare and family work. However, this amendment in family policies did not apply to the interviewed fathers in the presented empirical sample. Previous forms of childcare benefits likewise pursued the goal of promoting men's participation in childcare at an early stage in family life.

In a recent paper, Eva-Maria Schmidt, an Austrian sociologist focusing on the family, analysed the status quo of the Austrian childcare allowance system: "[P]arents tend to realise traditional parenting roles and largely [ 65 per cent] opt for a leave duration of at least 24 months, mainly taken by mothers (quoted in BMFJ 2016). Fathers tend to work full-time no matter how old their children are (quoted in Statistics Austria 2014)." (Schmidt 2018, p. 449f)

Since March 2017, fathers can receive a family-time bonus, "[A] monetary benefit for employed fathers who exclusively dedicate their time to their family within 91 calendar days after the birth of a child, i.e., interrupt their employment [in agreement with the employer] for a full-time leave period between 28 and 31 days." (Rille-Pfeiffer et al. 2018, p. 58) The income compensation for fathers who have received this benefit and later also take childcare benefits, is reduced by the amount of the family-time bonus.

Moreover, following EU directives on early childcare provisions and the promotion of women in the workplace, there has been an increase in public childcare facilities for children under the age of three in Austria, which has contributed to an earlier return to gainful work for both parents.

\section{Materials and Methods}

The presented research introduces modes of childcare division that differ from the norm in Austria. The three research projects included were conducted between 2013 and 2017. The first project, conducted in 2013, consisted of 22 interviews with men on paternal leave (see Table 2). It focused on everyday life experiences of men on paternal leave and qualitative analyses of the distribution of paid work, domestic work, and childcare. The second project investigated male-to-male relations, images of fatherhood held by the interviewees, the family of origin, images or role models for male caregivers, work-life-balance, and partnerships. This project was conducted between 2013 and 2014. The qualitative data corpus was derived from 50 guideline interviews, including 14 additional interviews in a follow-up study with men 
and women after the paternal leave period who reported on their arrangements in reconciling work and family and their work-life-balance. This further project represented a follow-up investigation on gender aspects in the (re)distribution of gainful and family work after paternal leave. The data were analysed using qualitative-interpretative methods.

The interview partners were contacted via parental networks, nursery schools, contacts provided by networks promoting caring men, and via offices providing support for fathers who aim to reconcile work and family (e.g., the Medical University of Vienna has launched programmes for male doctors). Moreover, several interview partners knew fathers on parental leave among their social circles and thus recommended that they participate in the study. Although, in general, the data generation focused on including men from different occupations, with different numbers of children, and different lengths of leave, the data analyses disclosed that most interview partners earned a good or above-average income and most had higher education. On the one hand, this might be explained by the contact offices, i.e., the mentioned personnel management programme launched by the Medical University of Vienna, or by the social contacts provided by interviewees, while on the other hand, a higher income might be a factor for participants in using the income-related childcare allowance model. As mentioned in the previous section on Austrian data, this is the model chosen by the greatest number of fathers. In addition, quantitative research in Austria as well as international qualitative studies confirm this higher percentage of parents with a good income and higher education in studies on parental leave (Riesenfelder 2015; Snitker 2018; Brumley 2018). Partly, also the average higher age of fathers on parental leave in Austria has an impact on this result, as 51 per cent of fathers on leave are 35 or older, whereas the share of women is 23 per cent in this age group. The figures show that women take parental leave at a younger age, 43 per cent are under 30 years old, and only 17 per cent of men taking childcare leave are in this age group (Riesenfelder 2015, p. 7). Moreover, to a certain extent, an interest in research and participating in studies might also be linked to the fact that people with higher education are more likely to participate in research. Even parents in the sample who worked part-time had relatively good, i.e., middle to above-average, incomes. The data set included three bi-national couples. Two female partners of interviewees and one male interviewee were born abroad (Nigeria, Palestine, Estonia). Their participation highlighted the transnational context of gendered expectations in generativity and family support. Investigating the effects of rather traditional family constellations, the presented empirical data analysis puts forward research in family and gender studies, as it investigated the impact of workplace settings and average time spent in gainful employment of both parents and the impact of this on intergenerational relationships in terms of financial support or care for elderly relatives.

Although the included fathers still represent a minority in Austria, as most have claimed long-term paternal leave, their individual outstanding progress in reconciling work and family is of great interest for evaluating the impact of current leave policies in Austria and making future changes in gender and family policies.

The data has shown employers' great relevance in supporting caring men. Hence, investigations on gender at work and gender in organizations are crucial for further explorations of the factors present that caused traditional gender arrangements in parenting, and on the other hand, were deregulated, as the qualitative data material shows. 
Table 2. Interview partners Project I—childcare allowance models, duration of paternal leave, gainful working hours both partners.

\begin{tabular}{|c|c|c|c|c|c|c|c|}
\hline IP & Age & Children & $\begin{array}{l}\text { Duration Paternal } \\
\text { Leave }\end{array}$ & Occupation & f Partner $\mathrm{h} /$ Week & Occupation Female Partner & Age $\mathrm{f}$ \\
\hline 1 & 35 & 1: $\mathrm{m}(2 ., \mathrm{f}$ born 2013) & $8 \mathrm{mo}$ & social sciences & full-time $/ 40 \mathrm{~h}$ & social work & 35 \\
\hline 2 & 37 & 2: $\mathrm{m} \mathrm{f}$ (paternal leave with 2nd child, $\mathrm{f})$ & $13 \mathrm{mo}$ & media (job change after leave) & full-time $/ 40 \mathrm{~h}$ & international organization & 38 \\
\hline 3 & 35 & 2: $\mathrm{m}$ w (pat. leave with 2nd child, + EL) & $2 \mathrm{mo}$ & psychologist (first employed, then free-lance) & $20 \mathrm{~h}$ & health scientist & 32 \\
\hline 4 & 33 & 2: $\mathrm{m} \mathrm{m}$, born 2013 (leave with first child, 2nd planned) & $10 \mathrm{mo}$ & controlling & $25 \mathrm{~h}$ & scientific employee, temporary contract & 33 \\
\hline 5 & 37 & 1: $\mathrm{m}$ & $11 \mathrm{mo}$ & lawyer, labour market policies & full-time & social work & 36 \\
\hline 6 & 35 & 2: $\mathrm{m} \mathrm{m}$ (twins) & $10 \mathrm{mo}$ & PR & $25 \mathrm{~h}$ & scientific employee & 33 \\
\hline 7 & 40 & 3: $\mathrm{m} \mathrm{ff}$ (3rd born 2013) & $6 \mathrm{mo}\left(\mathrm{E}^{*}\right)$ & energy economy & $32 \mathrm{~h}$ & psychologist, employment & 37 \\
\hline 8 & 40 & 2: $\mathrm{m} \mathrm{w}$ (2nd paternal leave) & 8 mo 2nd child & social work-leading position & $28 \mathrm{~h}$ & sabbatical/social work leading position & 36 \\
\hline 9 & 30 & $1: \mathrm{f}$ & $6 \mathrm{mo}$ & programmer/technical sciences & $30 \mathrm{~h}$ & $\mathrm{PhD} /$ economics/employment & 30 \\
\hline 10 & 35 & 2: $\mathrm{m} \mathrm{m}$ & $7 \mathrm{mo}$ & education & full-time & $\mathrm{PhD} /$ historian & 32 \\
\hline 11 & 37 & 2: ff (shorter parental leave with 2 nd child) & $12 \mathrm{mo}$ & chemistry & $35 \mathrm{~h}$ & NGO, educational sciences & 42 \\
\hline 12 & 47 & 3: $\mathrm{m} \mathrm{m} \mathrm{w} \mathrm{(second} \mathrm{leave:} \mathrm{baby} 3$ weeks) & $45 \mathrm{mo}\left(\mathrm{M}^{*}\right)$ & social work-leading position & $32 \mathrm{~h}$ & social work & 46 \\
\hline 13 & 34 & 1: $\mathrm{f}$ (second leave planned for 2014,6 months) & $6 \mathrm{mo}$ & scientific employee, English studies & full-time & PhD (humanities/cultural studies) & 31 \\
\hline 14 & 44 & $1: \mathrm{f}$ & $14 \mathrm{mo}(+\mathrm{EL})$ & social work-leading position & $32 \mathrm{~h}$ & social work-leading position & 40 \\
\hline 15 & 33 & 2: $\mathrm{m} \mathrm{f}$ (pat. leave with 2nd child) & $2 \mathrm{mo}$ & construction work & $20 \mathrm{~h}$ & PR & 34 \\
\hline 16 & 30 & $1: \mathrm{f}$ & $7 \mathrm{mo}$ & physics & $25 \mathrm{~h}$ & education & 27 \\
\hline 17 & 44 & 2: $\mathrm{ff}$ & $2 \mathrm{mo}+\mathrm{E}^{*}$ & social sciences & $25 \mathrm{~h}\left(\mathrm{E}^{*}\right)$ & scientific employee, public health organ. & 41 \\
\hline 18 & 43 & 2: $\mathrm{m} \mathrm{f}$ (pat. leave and $\mathrm{E}^{*} / \mathrm{EL} 2$ nd child) & $24 \mathrm{mo}+\mathrm{E}^{* *}$ & insurance company & $20 \mathrm{~h}$ & project assistant & 40 \\
\hline 19 & 42 & $2: \mathrm{ff}$ & $4 \mathrm{mo}$ & informatics, Federal Ministry & $16 \mathrm{~h}$ & freelance (coaching, vocational training) & 36 \\
\hline 20 & 39 & $\begin{array}{l}\text { 3: } \mathrm{m} \mathrm{m} \mathrm{m} \mathrm{(leave} \mathrm{with} \mathrm{second} \mathrm{child,} \mathrm{3rd} \mathrm{child} \mathrm{adult,} \mathrm{1st} \\
\text { of his partner }\end{array}$ & $15 \mathrm{mo}$ & project employment, social sciences & $30 \mathrm{~h}$ & education & 39 \\
\hline 21 & 47 & 1: $\mathrm{f}$ (second leave planned for 2015) & $3 \mathrm{mo}$ & lawyer, NGO; teaching & $30 \mathrm{~h}$ & NGO, employee & 33 \\
\hline 22 & 46 & 2: $\mathrm{m} \mathrm{m}$ & $\mathrm{E} * * *$ & freelance psychologist, coach & $24 \mathrm{~h}$ & labour market policies, leading position & 44 \\
\hline
\end{tabular}

$\left(\mathrm{E}^{* * *}\right)=$ freelance work (coaching, seminars, teaching), sharing childcare, household and gainful work with his partner; $(\mathrm{E} * *)=$ educational leave after paternal leave, parental part-time work afterward (case at court, getting income without returning to work for one year); $\left(\mathrm{E}^{*}\right)=$ parental part-time work before and after paternal leave; $\left(\mathrm{M}^{*}\right)=$ main caring person for the 3rd foster child from 3 weeks after birth; EL: Educational Leave = Leave for Educational Purposes; Full-time work in Austria in general varies between 38-40 h/week (very seldom $35-37.5 \mathrm{~h} /$ week). 
Methods

A qualitative-interpretative methodology was chosen as the research tool for analysing the relatively new phenomenon of paid paternal leave practices in Austria. Similar to the approaches of Grounded Theory (Strauss and Corbin 1990), the studies aimed at generating theories of medium range regarding men on parental leave, based on data beyond single cases. The data collection as well as the data evaluation followed this objective. The applied interview method was based on problem-centred interviews as developed by Witzel (2000). This technique combines qualitative, biographical, and process-orientated approaches, and is suitable for surveying data on isolated issues or problems, without neglecting the relevant settings of the interviewees. As defined by the problem-oriented interview, also questions regarding the current living situation and varying social fields (for example, occupation, number of children, living in a central or peripheral region) were asked to identify facets of parental leave and masculinity relevant to the research. The interviews took roughly one hour and were conducted at places chosen by the interviewees (at home, at the university, in a seminar room of an NGO, in various meeting rooms). The data set was recorded digitally and transcribed to allow in-depth data analysis. The data were coded and analysed step by step, open, axially, and finally, selectively. Whereas the first step remained close to the original text of the interview, each further step became more analytical. This method thus enabled clear messages regarding social phenomena, which make the individual cases abstract, but which are nonetheless grounded in fact. The data analyses of the follow-up studies were presented and discussed with (inter)national scholars in working group meetings, and evaluated with reference to quantitative national results (e.g., on part-time work). The interviews were conducted in German. The included quotes in this paper were translated by the author and checked by a professional translator.

\section{Results}

\subsection{Public Support and a High Level of Recognition for Fathers on Paternal Leave}

"It's extraordinary, nearly absurd, how overwhelmingly one is adored (as a father) for taking paternal leave, how wonderful one is, 'an exceptional (exemplary) father' (someone called after me as I went to grab a cup of coffee from a machine). No one has ever heard of an 'exceptional mother'." (IP 5,37 years old, lawyer, 1 son, 11 months on paternal leave, female partner, 35 years old, social work, full-time).

"Immediately: Here is the man with the child [ ... ] women probably won't get this kind of attention, being treated differently, in a friendlier way, a piece of a candy for the child, it's noticeable, very noticeable." (IP 10, teacher, 2 sons, 7 months on paternal leave, female partner, historian, PhD student, full-time).

In addition to positive feedback and a high level of public recognition, the interviewees reported a lot of support in daily life, especially when starting their paternal leaves: Receiving suntan lotion and hats for the children in summer time (IP 1), drinking water and pampers in children's playgrounds (IP 18), being accompanied by the children's grandmother when going to the play-grounds or visiting the doctor (IP 15), taking over contacts with other parents and small children from the female partner (IP 16), joining fathers-on-leave meetings and participating in fathers' clubs (after being told of them by the partner). Organizing social life, especially at the beginning of the leave period, was often inspired by the female partners. Most interviewees reported that meetings with other fathers or parents on leave with children of about the same age, or spending time together with the children and the partner were what characterised an ideal day during their leave periods.

In contrast, fathers who received a lower level of support, e.g., from grandparents and their partner in full-time gainful employment, reported time pressure during their leave, especially when having more than one child and accompanying the older child to a dance group, singing group, language course, or other educational setting for pre-school and elementary school children. 
Moreover, one father stated that the potential for recreation for him and other partners in childcare are lower when "mothers are present" (IP 34). He defined a perception of "educational imperatives" when the children's mothers are present, and wished for recreational holidays together with other fathers caring for children.

In general, at least in the beginning, fathers tended to see their parental leave periods as a contrast program to fulfilling daily schedules in gainful employment, and interpreted this time as one of recreation and leisure time with the child or children. Discussions between partners arose especially with regard to combining childcare with household chores. The combination of these duties, which women on parental leave often fulfilled during their leave period and consequently expected the same of their partners, caused even greater challenges when both partners returned to their gainful employment. In general, the positive recognition as a caring, active father was higher in the public sphere than at home. Correspondingly, fathers on paternal leave reported higher potential for joy derived from outdoor activities with their children, and having fun when spending time together with others, namely other parents on leave and with female partners after their return from the workplace. As described in Table 2, the interviewed sample of research project I revealed that two-thirds of the female partners worked part-time. This led to a high level of partner support in the private sphere, in child-care and performing household chores.

\subsection{Fathers on Leave Remaining in (Part-Time) Gainful Employment}

As opposed to mothers' first parental leave periods after the birth of a child with a complete stop of gainful employment for a certain period in most cases, a large number of interviewed fathers in the sample combined their periods of childcare benefits with part-time work (smaller projects, further income interests aside from their employment, such as social projects, teaching, holding seminars, publishing, research activities, and freelance projects). In some cases, they extended or substituted the parental leave with an educational leave. As fathers mostly took over later periods in parental leave, they had more time available for gainful employment projects than their female partners had in the first year or months after a child's birth.

Since there has been a recent increase in early childcare facilities in Austria, parents who take over a later childcare period after a child's first birthday may, if they so opt, profit more from this recent rise in public early childcare facilities. The qualitative sample especially in the second research project included men who combined the time during which they claimed childcare benefits with reduced working hours in their gainful employment (see Table 3, column "part-time work during paternal leave").

\subsection{Challenges in Realising a Long-Term Reconciliation of Work and Family}

The presented empirical sample confirmed that, in some cases, fathers took a shorter leave period than previously planned, or remained in part-time working contracts during their leave. This practice can be seen as a further tribute to a male breadwinner norm or function. This practice relies firstly on part-time-working women, and secondly on further persons involved in childcare, for instance grandparents or nannies, and is facilitated by a later time of paternal leave. In general, men reported a positive feedback with regard to their ambitions of being involved in the family. However, expectations in the workplace sometimes differed from a positive public perception of paternal leave:

"The working world is really hypocritical in this respect $[\ldots]$ truly a Potemkin village without any substance [ ... ]. Originally, the first reaction in my case was, 'do it, it's all right,' but when I really did go on leave, I heard comments like, 'if you had done this [in another company], they would have sacked you immediately". (IP 36, 37 years old, employee in a media department, 2 children, 1 year on paternity leave, changed job afterwards) 
Table 3. Interview partners Project II.

\begin{tabular}{|c|c|c|c|c|c|c|c|}
\hline $\begin{array}{l}\text { Interview } \\
\text { Partner }\end{array}$ & a & Children, Occupation & $\begin{array}{l}\text { Duration Paternal Leave, } \\
\text { Part-Time Work }\end{array}$ & Allowance Model & $\begin{array}{l}\text { Part-Time Work during } \\
\text { Paternal Leave }\end{array}$ & a f & $\begin{array}{l}\text { Female Partners' Occupation, during } \\
\text { Paternal Leave, Age and Working Time }\end{array}$ \\
\hline IP 23 & 35 & $\begin{array}{l}3(\mathrm{f} 6 \mathrm{a}, \mathrm{f} 4 \mathrm{a}, \mathrm{m} 2 \mathrm{a}) \text {, medical doctor in } \\
\text { education (waiting status for hospital } \\
\text { practice) }\end{array}$ & 3 years & $12+2$ & no & 33 & full-time embassy employee (reception) \\
\hline IP 24 & 39 & $\begin{array}{l}2 \text { (foster-) children }(1 \mathrm{f}, 1 \mathrm{~m}) \\
\text { psychologist }\end{array}$ & $\begin{array}{l}1 \text { year, then part-time } \\
30 \mathrm{~h} / \text { week }\end{array}$ & $20+4$ & $\begin{array}{l}\text { yes, begin of paternal leave: } \\
\text { freelance work, psychotherapy } \\
\text { in training }\end{array}$ & 42 & psychologist, psychotherapist in training \\
\hline IP 25 & 42 & $1(\mathrm{f} 1,5 \mathrm{a})$, journalist & $\begin{array}{l}6 \mathrm{mo} \text { ( } 2 \text { parental leave }+4 \mathrm{mo} \\
\text { educational leave) }\end{array}$ & $12+2$ & $\begin{array}{l}\text { partly (music interest, part of } \\
\text { employment) }\end{array}$ & $\mathrm{x}$ & $\begin{array}{l}\text { graphics/new media, shared parenthood } \\
\text { without cohabiting since the child's birth }\end{array}$ \\
\hline IP 26 & 47 & $\begin{array}{l}2(1 \mathrm{f}, 1 \mathrm{~m}) \text {, scientific employee } \\
\text { (admin) }\end{array}$ & $\begin{array}{l}2 \text { years pat. leave }+1 \text { parental } \\
\text { part-time work }\end{array}$ & $20+4$ & no & 40 & $\begin{array}{l}\text { historian, scientist, part-time employment } \\
20 \mathrm{~h} / \text { week and scientific free-lance work }\end{array}$ \\
\hline IP 27 & 36 & 1 (m), psychologist, employee & 1 year & $20+4$ & $\begin{array}{l}\text { Yes-offer return for } 1 \text { day, near } \\
\text { ending of pat. leave, } 10 \mathrm{~h} / \text { week }\end{array}$ & 34 & freelance photographer \\
\hline IP 28 & 26 & $\begin{array}{l}1(\mathrm{~m}, 5 \mathrm{mo}) \text {, police office/federal } \\
\text { employee }\end{array}$ & $\begin{array}{l}1 \text { "papa-month", } 2 \text { mo paternal } \\
\text { leave, } 2 \text { mo planned }\end{array}$ & $12+2$ & no & $\mathrm{x}$ & $\begin{array}{l}\text { entrepreneur, full-time (her company } \\
\text { located in Burgenland, partner works in } \\
\text { Vienna) }\end{array}$ \\
\hline IP 29 & 42 & $1(\mathrm{f}, 1,5 \mathrm{a})$, logistics / transports & $\begin{array}{l}3 \mathrm{mo} \text {, followed by parental } \\
\text { part-time }\end{array}$ & $15+3$ & no & 35 & psychological counselling, part-time \\
\hline IP 30 & 35 & $\begin{array}{l}1 \text { (m, } 9 \text { mo), NGO, precarious } \\
\text { employment (about } 20-30 \mathrm{~h} / \text { week) }\end{array}$ & $9 \mathrm{mo}$ & $20+4$ & $\begin{array}{l}\text { no (partly-NGO social } \\
\text { political involvement) }\end{array}$ & $\mathrm{x}$ & $\begin{array}{l}\text { full-time, male partner has changed } \\
\text { residence from Vienna to Graz }\end{array}$ \\
\hline IP 31 & 37 & $\begin{array}{l}1 \text { (m), civil servant, technical facility } \\
\text { management }\end{array}$ & $2 \mathrm{mo}$, then full-time & $12+2$ & no & 37 & civil servant/municipal of Vienna \\
\hline IP 32 & 30 & $2(1 \mathrm{f}, 1 \mathrm{~m})$, programmer/IT & $\begin{array}{l}6 \text { mo, later 3rd child + parent. } \\
\left.\text { part-time (proj. } V^{*}\right)\end{array}$ & $15+3$ & no & 30 & $\begin{array}{l}\text { economic and social scientist, changing } \\
\text { job to full-time }\end{array}$ \\
\hline IP 33 & 44 & 1 (f), social work & $\begin{array}{l}14 \mathrm{mo}(2 \text { paternal leaves and } 1 \\
\text { educational leave) }\end{array}$ & $12+2$ & yes (single projects) & 41 & social work, $32 \mathrm{~h} /$ week \\
\hline IP 34 & 47 & $\begin{array}{l}3 \text { foster/adopted children }(2 \mathrm{~m}, 1 \mathrm{f}) \text {, } \\
\text { social work }\end{array}$ & $\begin{array}{l}3 \text { years and } 8 \text { months, paternal } \\
\text { leave and part-time work }\end{array}$ & $30+6$ & $\begin{array}{l}\text { yes (teaching } 1 \text { lecture, } \\
1 \mathrm{~h} / \text { week semester) }\end{array}$ & 46 & social work, 30 h (partly 20 h) \\
\hline IP 35 & 43 & $\begin{array}{l}2(1 \mathrm{~m}, 1 \mathrm{f}) \text {, insurance company } \\
\text { employee (left job afterwards) }\end{array}$ & $\begin{array}{l}2 \text { mo paternal leave and } 1 \text { year } \\
\text { educational leave }\end{array}$ & $12+2$ & no & 40 & $\begin{array}{l}\text { university administration, employment } \\
30 \mathrm{~h} / \text { week }\end{array}$ \\
\hline IP 36 & 37 & $2,1 \mathrm{~m}, 1 \mathrm{f}$, journalist & 1 year paternal leave & $20+4$ & $\begin{array}{c}\text { yes (single } \\
\text { projects/publications) }\end{array}$ & 38 & full-time, internat. NGO \\
\hline
\end{tabular}

Legend: pat. leave: paternal leave $=$ parental leave: $\mathrm{a}=$ year $/ \mathrm{s}, \mathrm{mo}=$ month. educational leave $=$ allowance for educational purposes (studying, vocational training). ${ }^{*}$ proj. III $=$ Project III:

Outcome deriving from the interview on parental part-time work in 2016. 
Whereas men on leave reported challenges in realising childcare claims in negotiations with their employers, some female partners reported difficulties in finding full-time employment and permanent working contracts. Recent cuts in the public sector (health, education, social services) and some industrial branches have led to difficulties in starting a career, especially for women. An interviewee's statement on gender-mainstreaming ex negativo confirms these challenges:

"Inside these company structures, it really was a problem, well, there were co-workers, who also wanted to do parental part-time work [ ... ] when a superior signalled-I think I was affected too: 'If all the men go on leave now, why did we employ men in the first place?' ( ... ). This statement exposes the whole mentality, the structures. Because they deliberately employed fewer women exactly because women go on parental leave, and if the men are starting now, too, the whole structure will tumble". (IP 11, M., 37 years old, 2 daughters, parental leave 1st child 1 year-old, 2nd child six months-old)

\subsection{Gender Impact on Parental Leave Practices Influenced by Employers' Ideas of a Male Bread-Winner}

The empirical data divulged that men had to negotiate with employers at the workplace with regard to duration and time of their planned paternal leave period. In contrast, women's parental leave for roughly one year was more or less expected by the employer. Women were not asked, or if at all, less often, to stay in minor part-time employment during their parental leave or to return earlier than previously planned. Hence, the qualitative data showed that mainly fathers were asked to reduce their parental leave plans, or to postpone taking leave, or return to work earlier than planned, for some hours or a day per week. These details highlighted a traditional focus on men's presence at the workplace. Moreover, they revealed that men's presence in the private sphere is either not foreseen in employers' awareness, or not perceived as a substantial part of gender, family and intergenerational arrangements.

Moreover, the sample showed that men who planned to be involved in childcare and the management of the family on an equal basis were sometimes not taken seriously by their employers because the business' recruitment strategies followed a traditional male breadwinner norm. Conversely, individuals did not (fully) realise their parental leave plans due to the fear of consequences they would possibly have as involved parents (BMASGK 2017, pp. 42-43).

\subsection{Challenges within Family Life}

"A normal day, starting with getting up; I start with the negative and end with the positive: Negative is getting up [laughs], that's always chaotic. We started with 7.15 a.m., now we have arrived at 7.30 a.m. [ ... ]. The last five minutes [before leaving the apartment], no, the final act, [her son] putting on the shoes and the jacket, and our vestibule is very, very small, and every second day there is a fight. [The situation there] ends with saying tomorrow we have to deal with this differently. Meaning a fight between parents and Louis [her son who started attending school], or he looks wryly at his sister and she starts to cry and beats him, he beats back, no, it's like being a family of idiots, really [laughs]. That's totally chaotic, and I do not know how we can manage this [ ... ] I hope this is a phase [in the children's development], because at the moment all they do is beat each other. To go to sleep is exactly the opposite, this is always very beautiful". (Sana, partner of IP 3, 32 years old, health scientist, 2 children, 6 and 2 years old)

Transformations in family life, in the quote above, the son's entrance into school, always pointed to a higher prevalence of challenges in parental arrangements. Moreover, the empirical data hinted at a greater need for discussion when both parents had developed their own strategies with regard to health issues and nutrition.

"The health issue is one of our greatest problems. Our younger girl was ill recently [ ... ] also at the paediatrician's-you see a lot of men there, but they only have a supporting role, like driving mother and child there. When I accompany the older girl to the doctor and go to the pharmacy 
afterwards, I have the impression the doctor prescribes too much medication. [ ... ] And besides, there is the question, when is the right time to visit the paediatrician?"(IP 9, 32, 2 paternal leaves for half a year each).

Some fathers mentioned that they favoured male doctors, and had developed a good relationship with them. Others reported different strategies in preparing breakfast or not. How to motivate children to eat breakfast and to brush their teeth was mentioned several times in the interviews with fathers. The more involved fathers followed their own ideas in parenting and household management, the more both partners struggled in reconciling their individual career plans and parenting strategies.

"It is good that we can share duties, but there are also great efforts at discussion and finding a common solution. [ ... ] Especially in cases of differing points of view, a lot of energy must be invested, and it is a lot of work to balance them. How to find a good compromise, a common strategy that all family members agree upon? This progress doesn't just happen. During the parental leave it was easier, it was not a problem, as one parent concentrated on the child. Many challenges occurred when both of us returned to work". (female partner of IP 14, follow-up study after paternal leave)

In conclusion, gender equality was practiced and promoted by fathers' involvement in parental care. In most cases, this involvement triggered more sustained involvement when the childcare periods and parental leaves lasted six months or longer (see Tables 2 and 3).

However, men's participation is still seen as a voluntary tribute to the family, which is often a once in a lifetime matter (Mauerer 2018, p. 197; see also Mauerer 2016). On a broader social and cultural level, these individual commitments of fathers to spend time with their children and invest in family life are not always seen as self-evident responsibilities. Especially men's quotes on employers' interests in shorter leave periods specifically for men revealed forces that counteract the abolishment of gender imbalances in organizations. Moreover, the empirical data revealed structural challenges in realising paternal leave claims in Austria, especially in male-dominated sectors, such as natural sciences, engineering, and computer sciences. Although there has been substantial progress in enhancing the legal framework on paternal childcare allowance claims, especially in male dominated branches, the empirical results on paternal leave in Austria show that men often had attained a good professional reputation and certain position in the workplace before informing their superiors and claiming childcare allowance. Even when going on leave, their negotiations with employers showed tendencies of reducing the length of leave times or remaining as part-time employees during their childcare periods.

\subsection{Challenges in Measuring both Parents' Shares in Early Childcare and Parental Work in Dual-Career Families}

The empirical research revealed different strategies for reconciling work and family. It identified a high level of individual efforts in sharing childcare equally. Nevertheless, sharing parental leave on equal terms in terms of time (e.g., the mother staying at home for one year of a child's birth, the father the second year), was not a solid guarantee for equally sharing parental tasks and workloads.

"I would always plan my free time with my child, always, and he would often ask others to help take care of the child and he would meet his friends then, and so on. And now everything's kind of relative. And that is so to say, well, I think, it would be interesting to know if it's something connected to gender, I don't know actually, but I have the feeling that that's exactly how it is. Apart from that I haven't noticed anything else or maybe I didn't expect much or didn't expect anything else". (female partner of IP 14, follow-up study after paternal leave)

In the presented sample, some fathers reported that they wanted to change their job and that they were searching for a more family-friendly job during or after their parental leave (IP 29). One father 
stated that his employment situation was precarious (IP 30), another reported on a job change due to negative responses towards his long parental leave of one year at his former workplace (IP 36). One interview partner combined parental and educational leave, which led to a dismissal and new job. Nevertheless, the follow-up study revealed that this job change increased his job satisfaction and opened up better opportunities for reconciling work and family. In the two research projects, none of the fathers had severe problems finding a new or even better job in terms of reconciling work and family. This reveals that men with children are seen as loyal workers based on a male family breadwinner model, who-at least in the presented sample — can find new jobs relatively easily, supported by their partners in sharing family tasks and income gain. Fathers in organisations with low caring ethics, especially, developed a desire to change their employer. The follow-up study revealed that some fathers carried this out and changed their employer (IP 32, IP 35). Moreover, there were other external reasons for changes in employment. Some fathers started to increase their share of freelance work (IP 24, IP 27), others started, continued or completed another education that increased their opportunities to improve their workplace satisfaction or the long-term reconciliation of gainful employment and family work (IP 24, IP 27, IP 29, IP 33, IP 43), or freelance work and family work. In conclusion, also fathers in the presented sample reacted to changes in the setting of their employment. These shifts in the continuity of a gainful career impacted both partners' reconciliation of work and family and their dual career perspectives, including both partners' reconciliation of work and family.

\section{Discussion}

\subsection{Shifting Relationships within Gainful Employment, External Influences on Parents' Long-Term Reconciliation of Work and Family}

Investigating the causes for different pathways in sharing parental responsibilities and tasks in childcare, in her research on "Stay at home Dads (SAHDs) and Relationalities of Work and care in Canada and the United States" (Doucet 2016, p. 33f), the family researcher Andrea Doucet described a transformation in models of dual parenting, which were highly influenced by both partners' career pathways, including periods between jobs, dismissals, and changes in the labour market as such. In her work she states that "parallel to social and policy agendas that support fathers as workers and as caregivers, [ ... ], in Canada and the United states, the SAHDs concept is a family response to neoliberal restructuring" (Doucet 2016, p. 34). In reaction to the effects of recent and current shifts in the labour market, sometimes "the choice was made for us [for the parents and their forms of reconciling childcare and gainful work]". (Doucet 2016, p. 40f). I have investigated several labour market influences on parental decision-making, but in my sample, all of the fathers who decided to stay at home as primary caregivers also followed a gainful career parallel to this. Fathers staying at home as long-term primary caregivers for several years without looking for new employment did not exist in my empirical sample, in contrast also to the qualitative sociological findings from Cornelia Koppetsch and Sarah Speck in Germany (Koppetsch and Speck 2015). Different national leave regulations impact these (slight) differences in parental decision-making. Moreover, parental choices are also affected by different periods in parenting and different demands in childcare, e.g., in early childcare, when children start attending school, become teenagers, and so forth.

\subsection{Logics of Productivity Dominating Reproductive Demands}

International qualitative data on shared parenthood reveal diverse aspects of gender segregation in productive and reproductive work (O'Brien and Wall 2017b). Accordingly, the presented empirical data analysis clearly showed a logical order of productivity in family work, following a Fordist model in the private sphere. Nevertheless, the empirical analyses on managing or scheduling family life highlight the impact of the logic of production on the daily lives of all family members, evoking substantial time pressure caused by the subordination of reproductive work. This hierarchical order includes the devaluation of (former) duties in the private sphere (cleaning, household chores in general, 
keeping an overview, storing things, cooking and eating homemade food, etc.). As for individual contributions of men and women in family work and domestic labour, men on and after paternal leaves tended to compare their activities with those of other men, not with those of their partners (see Mikula et al. 2012). However, the empirical results show that especially fathers on long-term parental leave developed insights into the daily life with children.

Comparing international family policies, O'Brien and Wall (O'Brien and Wall 2017a, 2017b) identify two main important factors for promoting gender equality in reconciling work and parenthood: Duration and fathers' alone time with a child. Furthermore, they highlight the fact that fathers' paid leaves are an important base in family policies triggering men's ability to take care of a child on their own for at least one month, which is a crucial factor contributing to the positive effect on the amount of time fathers spend on childcare. The presented research confirms these results.

\subsection{Implementation of Caring Ethics in Organizations as a Tool for Closing the Gender Pay Gap}

The relatively slow progress in promoting paternal leave in relation to high efforts in family policies points to the need for amendments on a structural level in organizations and companies, especially with regard to men's long-term reconciliation of work and family. Introducing caring ethics at the corporate level could contribute to degenderizing existing gender disparities in gainful employment. Current analyses of strategies on claiming paternal leave reveal that there is a tendency to treat men's short-term childcare allowance claims as extended vacations or summer holidays with the family, "when the workload in the company is less and more people are off" (Bergmann and Schiffbänker 2016, p. 120). These individual strategies in claiming parental legal rights indicate the great pressure exerted on men (and women) in gainful employment. ${ }^{1}$

Although national public awareness-raising campaigns pursue the goal of men fighting together for the right to reconcile work and family, this is still lacking, as international family research identifies predominantly individual men as pioneering fathers (a.o., Wall and Leitão 2017; O'Brien and Wall 2017b; Nakazato 2017; Musumeci et al. 2015). However, paternal leave periods of two months have meanwhile come to be seen as "normal" both in the family and in the workplace in nations that have introduced individual, fully-compensated, and non-transferable father months, e.g., in Norway, Sweden, Iceland, Finland, and Canada (O'Brien and Wall 2017a, p. 258). This could be a start for further amendments leading to an extension of men's parental leave time and/or duration of childcare claims.

\subsection{Father-Child Relationship as Most Valuable Gain during and after Paternal Leave Periods}

Fathers reported a better relationship to their child or children during and after their parental leave.

"Consequently, being given the opportunity to spend time with the child for a longer period seems to promote the development of relational competence." (Kvande and Brandth 2017, p. 43).

In the present Austrian study, fathers on long-term leave for more than six months in particular reported that during the paternal leave period they had developed a better sense of "what has to be done" and a specific awareness of their child's needs (IP 24, 26, 32, 36, Table 3). Furthermore, interviewees stated that they had begun a good relationship to their child or children (see also Magaraggia 2013, and Brandth 2015), and family research also reveals positive effects on children's development (Cabrera 2016; Cabrera and Tamis-LeMonda 2013; Townsend 2002). Moreover, a positive

1 In a research presentation at the University of York in 2016, participants confirmed these hidden forms as a common practice also in the UK. These forms included, for example, taking "normal" vacation days after the birth of a child as a father, but not claiming fathers' days, although legal regulations for claiming paternity leave do exist. Furthermore, the discussion showed that employees tended to have a large amount of "open" vacation days that they could not or did not consume earlier due to heavy workloads. In that case, the birth of a child was a reason for claiming open vacation days (in scientific companies or entrepreneurial universities), but in general, there is no common tradition in claiming extra days despite a legal framework in national family policies. 
impact on the health of both fathers and children has been identified in correlation with fathers' involvement in childcare:

"Fathers who care for children early tend to stay more involved as children grow up. [ ... ] fathers who engage more with their children tend to report greater life satisfaction and better physical and mental health than those who care for and interact less with their children". (OECD 2016, p. 1)

Although family and gender policies aim at increasing paternal leave shares and promoting women in the workplace, economic and social influences deriving from labour market conditions, as well as social effects (peer-group influences, education, age) and economical influences (household income, the wider family, financial or social support) impact parental choices in sharing household chores, childcare, and gainful work.

\subsection{Economic Influences on Parental Choices}

Recent quantitative data have revealed that cuts in the public sector have targeted women and their gainful income to a higher extent, as they represent more employees in the health and care sector, in social and public services, as well as in education. Furthermore, (inter)national research and literature have revealed several aspects of gender inequalities in the working sphere, such as the higher share of women in public sectors that have undergone severe cuts (Walby 2015), or gender inequalities with regard to permanent and full-time work (a.o. Närvi 2012). In addition, expectations of caring motherhood and the further effects of a traditional sex-gender-system have caused a strong perpetuation of gender disparities at the workplace and the distribution of (re)productive work (BMASGK 2017; Walden 2016, p. 121; Funder 2016).

Discussing the results as effects of gender segregation in the workplace, there is a severe danger of "re/traditionalisation" and counter-active forces leading to the maintenance of traditional gender and family roles (Beham and Zartler 2006). In these traditional models, women have often participated voluntarily and unpaid in the private sphere, e.g., volunteering as helpers in childcare nurseries, in primary schools, in care for the elderly, and other settings.

Referring to national imbalances in parental leave practices, the family researchers Margaret O'Brien and Karin Wall indicated a "division [that] will emerge between parental leave-rich and parental leave-poor countries. Such a division could also occur within countries, [ ... ]. As result, poor parents have fewer options." (O'Brien and Wall 2017a, pp. 1-2).

Subsequently, exploring women's growing importance in earning a family income, the researchers Norman, Fagan and Elliot investigated the impact of women's return to the workplace on fathers' parenting practices (Fagan and Norman 2013, 2016; Norman et al. 2014). In contrast, persistent gender pay-gap effects lead to maintaining a traditional gendered work division in the private sphere, especially in fulfilling household chores, matters of health, care, and nutrition, and, in general, reproductive work.

Furthermore, in addition to different wage levels, gender pay-gap disparities underscore income differences in so-called male and female specific branches (see Mauerer 2010, pp. 85-111). This has a serious impact on women living alone or with children. It also has a profound, albeit hardly noted influence on parental and, in particular, paternal leave claims (see Norman et al. 2014).

Regarding the realisation of shared parenthood, presently both parents' gainful employment, the promotion of caring masculinities and fathers' steps toward becoming involved in childcare and managing household chores are on the agenda in (inter)national family and gender policies. However, "policies take time to be incorporated into attitudes, decision-making and behaviour" ( $\mathrm{O}^{\prime}$ Brien and Wall 2017a, p. 258). Indicating tools for supporting this change, as mentioned earlier, short-term paternal leave periods of two months are meanwhile accepted and considered "normal" in countries that have introduced a non-transferable, fully compensated fathers' quotas (O'Brien and Wall 2017a, p. 258). Nevertheless, long term arrangements in family care have not yet been realised Moreover, 
full income compensation for mothers during their entire leave entitlements including pension fund payments could prevent financial strains on women-as "second earners" even during parental leave periods-and reduce family dependencies deriving from a male bread-winner (model). Subsequently, attracting more fathers to take leave and also balancing the existing gender pay gap are ongoing tasks that require further changes in and strengthening of family, gender and social policies (see also Gíslason 2017, Eydal et al. 2015, Wall and Escobedo 2013).

\section{Conclusions and Outlook}

The presented research revealed the gender impact of parental leave practices in Austria in the private and public spheres and especially at the workplace. Challenges and strains for dual-career families in reconciling work and family were shown at various levels. The dual-career couples were faced with the problem of scheduling parental tasks equally between both partners, while both partners must deal with managing family and career demands. Moreover, different methods and educational views led to the need for clarification between partners, which, to a certain extent, resulted in new work-loads. As one interview partner in the research stated, similar to the qualitative results of Koppetsch and Speck (2015) in Germany, sometimes responsibilities and decisions in daily family life are easier to manage if one parent is in charge. During longer periods in family life, the mother was, for the most part, the key parent responsible for caregiving within a family, and therefore, some activities in daily life required no further discussion, as there was no question as to who was responsible.

As a first step toward lowering gender inequality in childcare, parents had to work toward finding ways of coming to a consensus or accepting differences in methods for dealing with daily routines such as how to react when children do not want to eat breakfast early in the morning, brush their teeth, or which physician to consult in cases when parents have different views and preferences in opting for a certain doctor. The examples from the interviews revealed a wide range of new experiences for fathers and parents in childcare and in their management of work and family.

Even more so than in the private sphere, gendered expectations at the workplace impacted parental decisions and choices with regard to the length of parental leave periods. Whereas mothers were mainly seen as the primary caregiving parent in the view of their employers, fathers were mainly perceived as family breadwinners, resulting in different workforce planning strategies among employers. While returning mothers sometimes had to insist on further acceptance as responsible and loyal workers at the workplace, who still identified with the company or organization after having become a parent, fathers had to insist more strongly on family-friendly employment conditions and push for the realisation of their parental leave in negotiations with employers. In some cases, especially in male-dominated branches, men decided to change their place of employment, as their wish for reconciling work and family was easier to realise in a new work environment. Furthermore, the results have shown that in branches in which the reconciliation of work and family was initially established for promoting women at the workplace, new opportunities opened up for men in the reconciliation of work and family, as these branches (mainly education, social care and health care, administration) were primarily perceived as female branches, and to a higher degree, had institutionalised the reconciliation of work and family. In these branches, men were able to more easily follow the steps and paths made available by realised gender-equality measures. Thus, gender-equality programmes that were first established with a focus on promoting women at the workplace also created better conditions for men's reconciliation of work and family.

In contrast, the promotion of women in so-called male-dominated branches is still limited. In these branches, parenting for both men and women is viewed as a private luxury and responsibility which often has to be denied, e.g., by not becoming parents, delegated to privately organised family support or public institutions, or downgraded and concealed by not showing the time strain of a family or mentioning responsibilities demanded by family life. In a variety of different settings, the aforementioned gender impact influences the awareness and perception of parental responsibilities and opportunities offered to individuals at the workplace and in the labour market more generally. 
All in all, men as parents tend to receive more support than women, and from women, in the private sphere when becoming a parent. In contrast, at the workplace they are often confronted with new demands and tasks, as employers' traditional views focus on men as being more loyal and responsible workers after having founded a family. This coincidence causes conflicts of loyalty, especially for fathers when opting for parental leave. As a result, they often stay in close contact with their employer, and some remain in part-time employment during the period when claiming childcare allowance. Thus, their parental leave results in substantially reduced hours, which was also shown in the presented examples. Some fathers opted to decrease their working time and focused on specific workloads in their existing employment or on new fields and other tasks.

In conclusion, gendered views with regard to the image of a loyal worker, which in Austria are also highly impacted by the perception of being present at the workplace, or being represented by subordinates, result in better conditions for fathers who have gained a certain position and good reputation at their place of employment. This means that young fathers at the start of their career are confronted with greater challenges in obtaining parental leave, which is also represented by quantitative figures which indicate an on average higher age of fathers when taking up parental leave (see subchapter 4, referring to Riesenfelder 2015, p. 7). Thus, future family, gender and social policies must focus on enabling younger men in the workplace to more easily reconcile work and family, as especially in that age group, images of a male bread-winner conceal and counteract men's wishes and ambitions to go on parental leave. Moreover, their ambitions of sharing childcare and family duties in the long term are substantially hindered by traditional views and expectations of employers with regard to male family-bread-winner roles. In that respect, the promotion of women in the workplace is still a main policy goal, which must be pursued in family, gender and social policies, as women's earned income in several branches is much too low to maintain a family. Women's low incomes also result in the pressure for young men, in particular, to opt for and follow career pathways as a main family breadwinner in the workplace.

The realisation and transfer of gender-equality programmes in the future planning of family policies and childcare allowance models is key to abolishing gender inequalities in reconciling childcare and gainful work, and on the other hand, to increasing men's and women's equal opportunities to realise parental responsibilities and pleasures. Moreover, raising awareness at the level of companies and organisations must be strengthened as goals also for family and gender policies, to revise employers' traditionally gendered views of their employees. In that respect, greater promotion could be given to women at the workplace who are supported by partners on parental leave.

Funding: This research was partly funded by the University Jubilee Foundation of the City of Vienna (Hochschuljubiläumsstiftung der Stadt Wien) under grant number H-275602/2013 (research conduction in collaboration with Paul Scheibelhofer) and by the Magistrate 7, Science Department, Municipal funding Vienna, grant number MA 7-184748/13 and grant number MA 7-944695/16.

Acknowledgments: I would like to thank the anonymous reviewers and Lisa Rosenblatt for their valuable comments. Their generous support and advice helped me better clarify the structure of the Austrian childcare allowance system, revise the introduction and background of my research and led to a more detailed presentation of my research results and their conclusions.

Conflicts of Interest: The author declares no conflicts of interest.

\section{References}

Acker, Joan. 2012. Gendered Organizations and Intersectionality: Problem and Possibilities, Equality, Diversity and Inclusion. An International Journal 31: 214-24.

Beham, Martina, and Ulrike Zartler. 2006. Retraditionalisierung und ihre Folgen-Väter und Scheidungsrisiko. Edited by Harald Werneck, Martina Beham and Doris Palz. Gießen: Psychsozial-Verlag, pp. 37-51.

Berghammer, Caroline. 2014. The return of the male breadwinner model? Educational effects on parents' work arrangements in Austria, 1980-2009. Work, Employment and Society 28: 611-32. [CrossRef] 
Bergmann, Nadja, and Helene Schiffbänker. 2016. Work-Life Balance and Fathers in Austria? Empirical Evidence at the Copany Level. In Balancing Work and Family in a Changing Society: The Fathers' Perspective. Edited by Isabella Crespi and Elisabetta Ruspini. New York: Palgrave Macmillan, pp. 113-27.

Bergmann, Nadia, Claudia Sorger, Barbara Willsberger, and Omar Yagoub. 2017. Männer und Vereinbarkeit von Beruf und Familie in männerdominierten Branchen: Betriebliche Fallbeispiele. Supported by the Equality Rights and Citizenship Programme of the European Union (2014-2020). Available online: http:/ / www.abzaustria.at/sites / default/files/files/Bericht-LuR-Sozialforschung-Maenner-Vereinbarkeit-2017.pdf (accessed on 20 October 2018).

Blair-Loy, Mary, Arlie R. Hochschild, Allison J. Pugh, Joan C. Williams, and Heidi Hartmann. 2015. Stability and transformation in gender, work, and family: Insights from the second shift for the next quarter century. Community, Work \& Family 18: 435-54. [CrossRef]

BMASGK-Federal Ministry of Labor, Social Affairs and Health and Consumer Protection. 2017. Parental Involvement. EU-Project: Men and Reconciliation of Work and Family: Supporting the Path to Gender Equal Distribution of Parental Leave and Working Time. Final Report, Vienna: Federal Ministry of Labor, Social Affairs, Health and Consumer Protection. Available online: http://maennerundvereinbarkeit.at/wp-content/ uploads/2018/03/Final-Report-to-a-Broader-Public-EN-final.pdf (accessed on 24 October 2018).

BMFJ—Federal Ministry for Families and Youth. 2016. Statistics Fathers' Involvement-Evaluation. Available online: https:/ / www.frauen-familien-jugend.bka.gv.at/familie/finanzielle-unterstuetzungen/kinderbetreuungsgeldbis-28.2.2017/statistik-vaeterbeteiligung--auswertung.html (accessed on 20 October 2018).

Brandth, Berit. 2015. Rural masculinities and fathering practices. Gender, Place \& Culture 23: 435-50. [CrossRef]

Brandth, Berit, and Elin Kvande. 2016. Fathers and flexible parental leave. Work, Employment and Society 30: 275-90. [CrossRef]

Brumley, Krista M. 2018. 'Involved' Fathers, 'Ideal' Workers? Fathers' Work-family Experiences in the United States. In Fathers, Childcare and Work. Contemporary Perspectives in Family Research. Emerald Series. Edited by Rosy Musumeci and Arianna Santero. Bingley: Emerald Publishing Limited, vol. 12, pp. 209-32.

Cabrera, Natasha. 2016. Why do fathers matter for children's development? In National Symposium on Family Issues. Gender and Couple Relationships. Edited by Susan M. McHale, Valarie King, Jennifer Van Hook and Alan Booth. Cham: Springer International Publishing, pp. 161-68.

Cabrera, Natasha J., and Catherine Tamis-LeMonda, eds. 2013. Handbook of Father Involvement: Multidisciplinary Perspectives. New York: Taylor \& Francis.

Ciccia, Rossella, and Mieke Verloo. 2012. Parental leave regulations and the persistence of the male breadwinner model: Using fuzzy-set ideal type analysis to assess gender equality in an enlarged Europe. Journal of European Social Policy 22: 507-28. [CrossRef]

Collinson, David L., and Jeff Hearn. 1994. Naming men as men: implications for work, organization and management. Gender, Work and Organization 1: 2-22. [CrossRef]

Crespi, Isabella, and Elisabetta Ruspini, eds. 2016. Balancing Work and Family in a Changing Society: The Fathers' Perspective. London: Macmillan.

Dearing, Helene. 2016. Gender equality in the division of work: How to assess European leave policies regarding their compliance with an ideal leave model. Journal of European Social Policy 26: 234-47. [CrossRef]

Doucet, Andrea. 2016. "The choice was made for us": Stay-At-Home Dads (SAHDs) and Relationalities of Work and Care in Canada and the United States. In Balancing Work and Family in a Changing Society: The Fathers' Perspective. Edited by Isabella Crespi and Elisabetta Ruspini. London: Macmillan.

European Institute for Gender Equality-EIGE. 2015. Country profile of Austria-Gender Equality Index 2015. Available online: https:/ / eige.europa.eu/rdc/eige-publications/austria-gender-equality-index-2015 (accessed on 5 November 2018).

EIGE (European Institute for Gender Equality). 2017. Gender Equality Index 2017. Measuring Gender Equality in the European Union 2005-2015. Luxembourg: Publications Office of the European Union, ISBN 978-92-9493-768-1.

Elliott, Karla. 2016. Caring Masculinities. Theorizing an Emerging Concept. Men and Masculinities 19: $240-59$. [CrossRef]

Escobedo, Anna, and Karin Wall. 2015. Leave policies in Southern Europe: continuities and changes. Community, Work E Family 18: 218-35. [CrossRef]

Eurostat. 2016. Gender Pay Gap Statistics. Available online: https:/ / ec.europa.eu/eurostat/statistics-explained/ index.php/Gender_pay_gap_statistics (accessed on 5 November 2018). 
Eydal, Guðný Björk, and Tine Rostgaard. 2018. Policies Promoting Active Fatherhood in Five Nordic Countries. In Fathers, Childcare and Work, Contemporary Perspectives in Family Research. Edited by Arianna Santero and Rosy Musumeci. Bingley: Emerald Publishing Limited, vol. 12, pp. 257-79.

Eydal, Guðný Björk, Ingólfur V. Gíslason, Tine Rostgaard, Berit Brandth, Ann-Zofie Duvander, and Johanna Lammi-Taskula. 2015. Trends in parental leave in the Nordic countries: Has the forward march of gender equality halted? Community, Work E Family 18: 167-81. [CrossRef]

Fagan, Colette, and Helen Norman. 2013. Men and gender equality: Tackling gender segregation in family roles and in social care jobs. In Gender and the European Labor Market. Edited by Francesca Bettio, Jannecke Plantenga and Mark Smith. Oxon: Routledge, pp. 199-223.

Fagan, Colette, and Helen Norman. 2016. Which Fathers Are Involved in Caring for Pre-school Age Children in the United Kingdom? A Longitudinal Analysis of the Influence of Work Hours in Employment on Shared Childcare Arrangements in Couple Households. In Balancing Work and Family in a Changing Society: The Fathers' Perspective. Edited by Isabella Crespi and Elisabetta Ruspini. New York: Palgrave Macmillan Ltd., pp. 83-98.

Funder, Maria. 2016. Arbeits-und Geschlechterpolitik—zur Wirkungsmacht der "(Gender) Relations of Production". In Genderpolitik. Konzepte, Analysen und Befunde aus Wirtschaft und Politik. Edited by Elke Wiechmann. Baden-Baden: Nomos, pp. 25-48.

Gíslason, Ingólfur V. 2017. Fathers on leave alone in Iceland: Normal Paternal Behavior? In Fathers on Leave Alone: Work-life Balance and Gender Equality in Comparative Perspective. Edited by Margareth O'Brien and Karin Wall. Basel: Springer International Publishing AG, pp. 147-62.

Haataja, Anita. 2009. Fathers' Use of Paternity and Parental Leave in the Nordic Countries. KELA Online Working Papers 2. Available online: https://helda.helsinki.fi/bitstream/handle/10250/8370/FathersLeaves_Nordic. pdf (accessed on 5 March 2018).

Hausen, Karin. 1997. Arbeiterinnenschutz, Mutterschutz und gesetzliche Krankenversicherung im Deutschen Kaiserreich und in der Weimarer Republik. Zur Funktion von Arbeits- und Sozialrecht für die Normierung und Stabilisierung der Geschlechterverhältnisse. In Frauen in der Geschichte des Rechts. Von der frühen Neuzeit bis zur Gegenwart. Edited by Ute Gerhard. München: C.H. Beck Verlag, pp. 713-43.

Koppetsch, Cornelia, and Sarah Speck. 2015. Wenn der Mann kein Ernährer mehr ist: Geschlechterkonflikte in Krisenzeiten. Berlin: Suhrkamp.

Kvande, Elin, and Berit Brandth. 2017. Fathers on Leave alone in Norway: Changes and Continuities. In Fathers on Leave Alone: Work-life Balance and Gender Equality in Comparative Perspective. Edited by Margaret O'Brien and Karin Wall. Basel: Springer International Publishing AG, pp. 29-43.

Magaraggia, Sveva. 2013. Tensions between fatherhood and the social construction of masculinity in Italy. Current Sociology 61: 76-92. Available online: http:/ / csi.sagepub.com/content/61/1/76.full (accessed on 20 October 2018). [CrossRef]

Matsuda, Tomoko, Saori Kamano, Mieko Takahashi, Setsuko Onode, and Kyoko Yoshizumi. In Balancing Work and Family in a Changing Society: The Fathers' Perspective. Edited by Isabella Crespi and Elisabetta Ruspini. New York: Palgrave Macmillan, pp. 99-112.

Mauerer, Gerlinde. 2010. Weiblichkeit und (Vor-)Sorge tragen: Wechselwirkungen zwischen Frauen- und Krankheitsbildern. In Frauengesundheit in Theorie und Praxis: Feministische Perspektiven in den Gesundheitswissenschaften. Edited by Gerlinde Mauerer. Bielefeld: Transcript, pp. 85-112.

Mauerer, Gerlinde. 2016. Vaterliebe, Familienarbeit und Beruf: “Abweichendes Verhalten” oder neue Maßstäbe? Qualitative Forschungsergebnisse zu Väterkarenzen und Elternteilzeitarbeit in Österreich. In Gesellschaft im Wandel, Reihe University—Society—Industry. Beiträge zum lebensbegleitenden Lernen und Wissenstransfer. Band: Nino Tomaschek und Judith Fritz, Postgraduate Center der Universität Wien (Hrsg.), vol. 5, pp. 135-54.

Mauerer, Gerlinde. 2018. Paternal Leave and Part-Time Work in Austria: Rearranging Family Life. In Fathers, Childcare and Work. Contemporary Perspectives in Family Research. Edited by Rosy Musumeci and Arianna Santero. Bingley: Emerald Publishing Limited, vol. 12, pp. 183-207.

Mikula, Gerold, Bernhard Riederer, and Otto Bodi. 2012. Perceived justice in the division of domestic labor: Actor and partner effects. Personal Relationships 19: 680-95. [CrossRef]

Musumeci, Rosy, and Arianna Santero, eds. 2108. Fathers, Childcare and Work: Cultures, Practices and Policies, Contemporary Perspectives in Family Research Volume 12. Emerald Series; Bingley: Emerald Publishing Limited. 
Musumeci, Rosy, Naldini Manuela, and Adriana Santero. 2015. First-time fathers and childcare. Persistence and innovation in the Italian fatherhood regime. Interdisciplinary Journal of Family Studies XX 1: 1-19.

Nakazato, Hideki. 2017. Fathers on Leave Alone in Japan: The Lived Experiences of Pioneers. In Fathers on Leave Alone: Work-life Balance and Gender Equality in Comparative Perspectives. Edited by Margareth O'Brien and Karin Wall. Basel: Springer International Publishing AG, pp. 231-56.

Närvi, Johanna. 2012. Negotiating care and career within institutional constraints-Work insecurity and gendered ideals of parenthood in Finland. Community, Work E Family 15: 451-70. [CrossRef]

Neyer, Gerda R. 1997. Die Entwicklung des Mutterschutzes in der Schweiz, Deutschland undÖsterreich von 1877 bis 1945. In Frauen in der Geschichte des Rechts. Von der frühen Neuzeit bis zur Gegenwart. Edited by Ute Gerhard. München: C.H. Beck Verlag, pp. 744-58.

Norman, Helen, Marc Elliot, and Colette Fagan. 2014. Which fathers are the most involved in taking care of their toddlers in the UK? An investigation of the predictors of paternal involvement. Community, Work $\mathcal{E}$ Family 17: 163-80. Available online: http:/ / www.tandfonline.com/doi/pdf/10.1080/13668803.2013.862361 (accessed on 20 October 2018).

O'Brien, Margaret, and Karin Wall, eds. 2017a. Fathers on Leave Alone: Work-life Balance and Gender Equality in Comparative Perspective. Basel: Springer International Publishing AG. Available online: https:/ /link.springer. com/content/pdf/10.1007\%2F978-3-319-42970-0.pdf (accessed on 13 December 2018).

O’Brien, Margaret, and Karin Wall. 2017b. “Home Alone” Parental Leave for Dads Transforms Fatherhood. Available online: https://childandfamilyblog.com/home-alone-parental-leave-fatherhood (accessed on 23 October 2018).

O'Brien, Margaret, Berit Brandth, and Elin Kvande. 2007. Fathers, Work and Family Life: Global Perspectives and New Insights. Community, Work \& Family 10: 375-86.

OECD. 2016. Policy Brief March. Parental Leave: Where Are the Fathers? Men's Uptake of Parental Leave is Rising but Still Low. Available online: https:/ /www.oecd.org/policy-briefs/parental-leave-where-are-thefathers.pdf (accessed on 10 October 2018).

Riesenfelder, Andreas. 2015. Wiedereinstiegsmonitoring Österreich. Kohorten 2006 bis 2012. Wien. Available online: http:/ / media.arbeiterkammer.at/PDF/WIMON_Oesterreich_Datenband_2006-2012.pdf (accessed on 22 October 2018).

Rille-Pfeiffer, Christiane, Helene Dearing, and Andrea E. Schmidt. 2018. Note on Austria. In 14th International Review of Leave Policies and Related Research 2018. Edited by Sonja Blum, Alison Kowlowski, Alexandra Macht and Peter Moss. pp. 57-65. Available online: https://www.leavenetwork.org/fileadmin/user_upload/k_ leavenetwork/annual_reviews/Leave_Review_2018.pdf (accessed on 22 October 2018).

Salin, Milla, Minna Ylikänno, and Mia Hakovirta. 2018. How to Divide Paid Work and Unpaid Care between Parents? Comparison of Attitudes in 22 Western Countries. Social Science 7: 188. [CrossRef]

Schmidt, Eva-Maria. 2018. Breadwinning as care? The meaning of paid work in mothers' and fathers' constructions of parenting. Community, Work E Family 21: 445-62. [CrossRef]

Schmidt, Eva-Maria, Irene Rieder, Ulrike Zartler, Cornelia Schadler, and Rudolf Richter. 2015. Parental constructions of masculinity at the transition to parenthood: The division of parental leave among Austrian couples. International Review of Sociology 25: 373-86. [CrossRef]

Snitker, Aundrea. 2018. Not Mr. Mom: Navigating Discourses for Stay-at-Home Fathers. Available online: http:/ /journals.sagepub.com/doi/abs/10.1177/1060826518758628 (accessed on 18 October 2018).

Statistics Austria. 2014. Family and Employment 2013. Available online: http://www.statistik.at/web_de/static/ familie_und_erwerbstaetigkeit_2013_080941.pdf (accessed on 13 December 2018).

Statistics Austria. 2016. Kinderbetreuungsgeldbezieherinnen und-bezieher nach Geschlecht 2008-2015. Available online: http://www.statistik-austria.at/web_de/statistiken/menschen_und_gesellschaft/ soziales/sozialleistungen_auf_bundesebene/familienleistungen/058447.html (accessed on 21 October 2018).

Statistics, Austria. Kinderbetreuungsgeldbezieherinnen und -bezieher nach Geschlecht 2008-2017. Available online: http:/ /www.statistik.at/web_de/statistiken/menschen_und_gesellschaft/soziales/sozialleistungen_ auf_bundesebene/familienleistungen/058447.html (accessed on 13 December 2018).

Strauss, Anselm, and Juliet Corbin. 1990. Basics of Qualitative Research. Grounded Theory Procedures and Techniques. London: SAGE.

Townsend, Nicholas W. 2002. The Package Deal. Marriage, Work and Fatherhood in Men's Lives. Philadelphia: Temple University Press. 
Walby, Sylvia. 2015. Crisis. Cambridge: Polity Press.

Walden, Karin. 2016. Arbeitszeit- und Vereinbarungspolitik-Mehr Talk als Action? In Genderpolitik. Konzepte, Analysen und Befunde aus Wirtschaft und Politik. Edited by Elke Wiechmann. Baden-Baden: Nomos Verlagsgesellschaft, pp. 107-25.

Wall, Karin, and Anna Escobedo. 2013. Parental leave policies, gender equity and family well-being in Europe: A comparative perspective. In Family Well-Being. European Perspectives. Social Indicator Research Series. Edited by Almudena Moreno Mínguez. Dordrecht: Springer, pp. 103-29.

Wall, Karin, and Mafalda Leitão. 2017. Fathers on Leave Alone in Portugal. Lived Experiences and Impact of Forerunner fathers. In Fathers on Leave Alone: Work-life Balance and Gender Equality in Comparative Perspectives. Edited by Margaret O'Brien and Karin Wall. Basel: Springer International Publishing AG, pp. 45-68.

Witzel, Andreas. 2000. The problem-centered interview. Forum Qualitative Research 1: 22. Available online: http: / / www.qualitative-research.net/index.php/fqs/article/view/1132/2519 (accessed on 13 December 2018).

(C) 2018 by the author. Licensee MDPI, Basel, Switzerland. This article is an open access article distributed under the terms and conditions of the Creative Commons Attribution (CC BY) license (http:/ / creativecommons.org/licenses/by/4.0/). 